\title{
In vivo anti-inflammatory, antipyretic, analgesic activity and in vitro anti- proliferative activity of aqueous methanolic extract of Euphorbia granulata Forssk
}

\author{
Mohsin Ahmad Ghauri ${ }^{1}$, Liaqat Iqbal ${ }^{1}$, Ali Raza ${ }^{2}$, Uzma Hayat $^{2}$, Naveel Atif ${ }^{3}$ and Aqeel Javeed ${ }^{1 *}$ (1)
}

\begin{abstract}
Background: Naturally occurring substances of plant origin have long been used in folk medicine for curing various ailments including fever, pain, and inflammation etc. After careful evaluation on scientific bases, a large number of those substances provides cheaper alternative to currently used synthetic or semi-synthetic agents. Thus, with an aim of discovering alternative medicine for treatment of such ailments, current study was carried out. Euphorbia granulata Forssk. had long been used as a therapeutic agent against various morbid conditions, e.g., anthelmintic, snake bite, scorpion sting, purgative, and diuretic, and as blood purifying agent in folk medicine. The purpose of the current study was to determine the extended therapeutic use of Euphorbia granulata Forssk. based upon scientific evaluation, to explore the potential of its anti-proliferative, analgesic, antipyretic, and antiinflammatory activities while using an aqueous methanol extract of the whole plant.
\end{abstract}

Results: In vivo study was performed on female rats of specie Rattus norvegicus weighing (100-150 g). Antiinflammatory activity of the plant extract was calculated against using carrageenan induced paw edema. Analgesic potential both central and peripheral was assessed by using Eddy's hot plate method and acetic acid-induced writhing model, respectively. The antipyretic potential was appraised using brewer's yeast suspension, injected under the nape of the neck, and body temperature was measured using a digital thermometer. The plant extract strengths used for in vivo experiments were $50 \mathrm{mg}, 100 \mathrm{mg}$, and $200 \mathrm{mg} / \mathrm{kg}$ (diluted in normal saline) and were administered through intra-peritoneal route. MTT assay was performed to estimate in vitro anti-proliferative potential. For this assay, a serial dilution of the plant extract was used with $100 \mu \mathrm{g} / \mathrm{ml}$ as the highest concentration. In vivo results demonstrated that plant extract at dose strength of $200 \mathrm{mg} / \mathrm{kg}$, showed significant $\left(p^{*}<0.05\right)$ antiinflammatory, analgesic, and antipyretic activities. In case of MTT assay, however, no significant anti-proliferative activity ( $p>0.05$ ) was observed up to $100 \mu \mathrm{g} / \mathrm{ml}$ dose strength.

Conclusion: It can be concluded that aqueous methanol extract of Euphorbia granulata (whole plant) have shown significant anti-inflammatory, analgesic, and anti-pyretic activity in animal model. Therefore it can be a potential candidate, as a therapeutic alternative against treatment of algesia, pyrexia, and inflammation of various pathological origin. However, the plant extract did not demonstrate any significant anti-proliferation activity at doses used in this study.

Keywords: Euphorbia granulata, Anti-inflammatory, Analgesic, Antipyretic, Cytotoxicity

\footnotetext{
* Correspondence: Leo_PharmD106@yahoo.com

'Department of Pharmacology and Toxicology, University of Veterinary and Animal Sciences, Lahore, Pakistan

Full list of author information is available at the end of the article
}

\section{Springer Open}

(c) The Author(s). 2021 Open Access This article is licensed under a Creative Commons Attribution 4.0 International License, which permits use, sharing, adaptation, distribution and reproduction in any medium or format, as long as you give appropriate credit to the original author(s) and the source, provide a link to the Creative Commons licence, and indicate if changes were made. The images or other third party material in this article are included in the article's Creative Commons licence, unless indicated otherwise in a credit line to the material. If material is not included in the article's Creative Commons licence and your intended use is not permitted by statutory regulation or exceeds the permitted use, you will need to obtain permission directly from the copyright holder. To view a copy of this licence, visit http://creativecommons.org/licenses/by/4.0/. 


\section{Background}

The naturally occurring plants are an excellent source of various therapeutic substances. The obtained active ingredients from these plants were used as remedy to combat various ailments [1]. Euphorbia granulata Forssk. (EG) have its place in the plant family Euphorbiaceae. It is locally found in African countries, distributed from drier ranges from Western Sahara and Morocco to Somalia, different countries of Middle East to Kenya and Tanzania, and from Arabian Peninsula and central Asia to China, Pakistan, and India [2]. Euphorbiaceae is among the family of flowering plants, comprising five subfamilies and approximately 300 plus genera and more than 7000 species [3]. EG is densely growing branched, annual, or perennial herb [4]. The plant extract is used as an anthelmintic agent, the latex is topically applied to treat scorpion stings and snake bites. It is also used as a blood purifier, diuretic agent, and purgative [5]. The plant has also demonstrated HIV-1 and HCV protease inhibitory potential [6]. The inflammation is believed to be a significant physiological defense mechanism that supports the body to pledge itself against allergens, toxic chemicals, blisters, infection, and various other noxious stimuli [7]. Uncontrolled and obstinate process of inflammation could be an etiologic factor for some of these enduring ailments. Even though the process of inflammation is a body's safeguard mechanism, yet the complicated events and mediators involved in the inflammatory process can be easily prompted [8]. Several natural substances of plant origin exhibit significant anti-proliferative propensity, e.g., Vinca alkaloids from periwinkle plant Catharanthus roseus. A large number of substances of plant origin are already under investigation for their anti-proliferative properties [9]. Analgesic is any substance that is used to provide relief from pain. The word analgesia originated from Greek and comprises of two parts, "an" meaning without and "gesic" that means pain. So the scholarly sense of analgesia is without pain. These representatives are commonly recognized as pain relievers. These drugs can act on peripheral and central nervous system through various mechanisms. These agents act differently from anesthetics to allay pain (reversibly eliminate agonizing sensation) [10]. The word antipyretic is also derived from two Greek words, "anti" means against and "pyretic" means fever. Antipyretic hence refer to those agents that reduces fever. These agents guide the hypothalamus brain region to overcome an interleukin-induced upsurge in temperature [11]. The body then acts through discharge of diverse substances to drop the temperature and diminish the fever [12]. The undesirable effects escorted with currently available synthetic anti-inflammatory, analgesic, anti-proliferators, and antipyretic drugs pose a major problem during their clinical use.
In the current study, the aqueous methanol extract (70:30) of the EG whole plant was utilized to appraise its analgesic, anti-inflammatory, and antipyretic potential in animal model, whereas MTT assay was performed to determine in vitro anti-proliferative potential of EG in human breast cancer cell lines MCF-7, MDA-MB-231, and SkBr3. Female Wistar rats of specie Rattus norvegicus were used for the in vivo study, the animal selection was based upon other activities of under-observation plant in different literature with same strain of experimental rats [13-17]. To the best of our knowledge, no work has yet been carried out to investigate the in vitro antiproliferative and in vivo anti-inflammatory, analgesic, and antipyretic effect of whole plant of EG. Therefore, with a view to discover alternative therapeutic options, with minimum side effects for aforesaid ailments, the current study was carried out.

\section{Methods \\ Plant material}

EG is a prostrate (stretched out with face on the ground in adoration), annual plant with branches up to $15 \mathrm{~cm}$ long; the whole plant appearance is short-hairy or sparsely furry. The plant is typically collected from the wild for native use. The official name of the plant is Euphorbia granulata Forssk. Common names include Euphorbia forsskaolii, Euphorbia turcomanica, lubaina, and spurge. Its local name is lubaina. In English, it is called as desert spurge. Whole plant EG was collected during the month of July-August (2017) from the peripheral areas of Khanewal city in Punjab province, Pakistan. Botanical identification was done from Government College University, Lahore, and a sample was retained there in the herbarium with a voucher number 3820/Bot. Moreover, the plant name has been checked with http://www.theplantlist.org for the accepted name in accordance with the International Plant Names Index (IPNI).

\section{Preparation of plant extract}

The non-essential elements from the collected material were detached mechanically and the whole plant was washed three times using distilled water. Subsequently, plant material was shade dried at temperature ranging between $\left(21-30^{\circ} \mathrm{C}\right)$ for 30 days. The dehydrated plant material was mechanically condensed to granular powder and stored in an air-tight vessel. From the obtained plant powder, approximately $500 \mathrm{~g}$ of material was taken in a large beaker thereafter; 2 liters of dichloromethane (DCM) was then added to it, and the mixture was then macerated for $72 \mathrm{~h}$ and then again macerated with methanol for $72 \mathrm{~h}$ with intermittent shaking and stirring. The filtrate was extracted three times with the fresh solvent and all the extract was then combined. Multilayered muslin cloth was used for coarse filtration of the 
macerated plant material. Once the coarse filtration is completed, the plant extract was filtered through Whatman no. 1 filter paper for fine filtration. The acquired filtrate was then resolved under reduced pressure (760 $\mathrm{mmHg}$ ) at $40{ }^{\circ} \mathrm{C}$ in a rotary evaporator (Heidolph Laborota 4000, USA). The semisolid mass assimilates indicated percentage yield of $29.6 \%$, and later it was desiccated in an oven at $40{ }^{\circ} \mathrm{C}$. To speed up the process of extraction, grinding was done and later size reduction was performed with a pestle and mortar. After size reduction, plant material was macerated in (70:30) water and methanol. The grinded material was macerated in aqueous methanol mixture three times, then filtered and evaporated on rotary evaporator $[18,19]$.

\section{Solvents and chemicals}

The standard drug indomethacin was locally acquired from Chiesi Pharmaceuticals, Pakistan; tramadol (Tonoflex injection) and paracetamol (Provas injection) were purchased from SAMI Pharmaceuticals Pvt. Ltd. Acetic acid and brewer's yeast was purchased from Punjab Chemicals Pvt. Ltd. Lahore, Pakistan. Carrageenan was purchased from Sigma Aldrich, USA. Sterile normal saline (NS) (PAKSOL pharmaceuticals pvt Ltd) and sterile water for injection was purchased from local distributer, Muller and Phipps (M\&P), Lahore, Pakistan. Dimethyl sulfoxide (DMSO) from Sigma Aldrich, USA; Dulbecco's modified Eagle medium (DMEM); Roswell Park Memorial Institute (RPMI 1640) and L15 complete medium from (Hyclone, USA); penicillin/streptomycin solution (Hyclone, USA); phosphate buffer saline (PBS; Hyclone, USA); fetal bovine serum (FBS; Hyclone, USA); MTT reagent (Bio world, Dublin); and trypsin (Hyclone, USA). The doses of the plant extract were prepared in DMSO and diluted in sterile normal saline under aseptic laboratory conditions in a clean room for all the experiments.

\section{Experimental animals}

With prior approval from the ethical committee for the animal experiments (Institutional Review Committee for Biomedical Research, University of Veterinary and Animal Sciences, Lahore, Pakistan), approval number is IRCBR/886-E-17/PCOL/UVAS. Wistar rats (female) aging 1 to 2 months of Rattus norvegicus species weighing 100-150 g were purchased from University of Health Sciences (UHS), Lahore. The experimental rats, (ER), now onwards, were retained under routine laboratory conditions of $22-25^{\circ} \mathrm{C}$ with alternate light/dark 12/12-h period. Pellet form feed was given to ER and water ad libitum. For every experiment, 20 ER were used and distributed randomly in five groups and each group comprises of four ER.

\section{Anti-inflammatory activity}

The anti-inflammatory strength of aqueous methanolic extract of whole plant was assessed against using carrageenan-induced paw edema model. ER were randomly divided into five groups counting four ER in each group. ER were deprived of feed $1 \mathrm{~h}$ before experiment. Group I was administered sterile normal saline as blank or negative control $10 \mathrm{ml} / \mathrm{kg}$; group II was given standard drug indomethacin $10 \mathrm{mg} / \mathrm{kg}$, as positive control; group III, IV, and V were given plant extract 50, 100, and $200 \mathrm{mg} / \mathrm{kg}$, respectively. After $1 \mathrm{~h}$ of intra-peritoneal (i.p.) administration of standard drug and plant extract, $1 \%$ carrageenan solution approximately $100 \mu \mathrm{l}$ was injected into the left hind paw of each ER as an inflammatory mediator. The paw volume of each ER was then determined immediately at $0 \mathrm{~h}$ and after $3 \mathrm{~h}$ of carrageenan injection using liquid immersion model [20]. To measure the volume of the paw edema, a glass beaker was filled with distilled water and positioned on a weighing balance; the weight of the beaker was tared. The paw volume of each ER was measured by immersion of the inflamed paw into water. A force $F$ is applied to the balance against the movement of liquid inside the beaker and that was equal to weight of the paw. The paw volume was measured using Eq. (1).

$$
\text { Volume }=(\text { Weight }) /(\text { Specific gravity of liquid })
$$

As the specific gravity of water at room temperature is taken as 1 so each $1 \mathrm{~g}$ increase in weight is equal to the $1 \mathrm{~cm}^{3}$ increase in volume.

The mean paw edema was calculated for all groups and compared, with that of negative control group. Percentage inhibition of the inflammation was then measured using Eq. (2) given as:

percentage inhibition $=((\mathrm{Vt}-\mathrm{Vo})$ control $-(\mathrm{Vt}-\mathrm{Vo})$ treated $) /(\mathrm{Vt}-\mathrm{Vo})$ control $\times 100$

where $\mathrm{Vt}$ is paw volume at time $t=3 \mathrm{~h}$ and Vo is volume at $0 \mathrm{~h}$ time.

\section{Analgesic activity \\ Eddy's hot plate model}

The ER were randomly distributed into five groups comprising four ER in each group. All animals were introverted from feed $2 \mathrm{~h}$ before the beginning of experiment. Pre-testing of ER on Eddy's hot plate kept at $55^{\circ} \mathrm{C} \pm$ $0.1^{\circ} \mathrm{C}$ was then performed. ER displaying latency time greater than $15 \mathrm{~s}$ were omitted from the experiment. In our study, none of the ER displayed latency time greater than $15 \mathrm{~s}$ in pre-testing examination so there was no exclusion. The groups were injected with the following: group I was injected sterile NS $10 \mathrm{ml} / \mathrm{kg}$; group II was given tramadol $20 \mathrm{mg} / \mathrm{kg}$; group III, IV, and V were 
given EG 50, 100, and $200 \mathrm{mg} / \mathrm{kg}$ via i.p. route of administration, respectively. Thirty minutes after administration of corresponding treatment, the ER were placed on Eddy's hot plate and latency time (time for which ER remained on the hot plate without licking or flicking of hind limb or jumping) was then measured for $1 \mathrm{~min}$ and recorded [21]. The percentage analgesia was calculated by Eq. (3).

$$
\begin{aligned}
& \text { percentage Analgesia }(\%) \\
& =\frac{\text { Test latency }- \text { Control latency }}{\text { Cut off time }- \text { Control latency }} \times 100
\end{aligned}
$$

\section{Writhing model}

ER were divided into five groups comprising four ER in each group. The peripheral analgesic potential was assessed by acetic acid-induced abdominal writhing. The groups were given with following: group I was administered sterile NS $10 \mathrm{ml} / \mathrm{kg}$; group II was administered indomethacin $10 \mathrm{mg} / \mathrm{kg}$; group III, IV, and V were administered plant extract 50,100, and $200 \mathrm{mg} / \mathrm{kg}$, respectively. After group treatment, approximately $50 \mu \mathrm{l}$ of $1 \%$ acetic acid solution in sterile NS was given to each ER through i.p. route of administration. Twenty minutes later, the abdominal constrictions or writhing was observed and counted for $1 \mathrm{~min}$ and recorded [22].

\section{Antipyretic activity}

\section{Brewer's yeast-induced pyrexia model}

Antipyretic strength of the plant extract was appraised against using methods previously described. ER were randomly allocated into five groups comprising four ER in each group. The standard body temperatures of the ER were examined by inserting a digital thermometer into their anal cavities for about $1 \mathrm{~min}$. The rectal temperature readings observed were recorded as pretreatment or normal body temperature. Thereafter, pathogenic fever was induced in ER by injecting 15\% brewer's yeast (Saccharomyces cerevisiae) suspension at dose adjustment of $1 \mathrm{ml} / \mathrm{kg}$, subcutaneously under the nape of the neck and $24 \mathrm{~h}$ later the rectal temperature of all the ER was measured again. ER that did not show a baseline increase of $0.3^{\circ} \mathrm{C}$ temperature was excluded from the study. In our study, none of the ER was omitted due to the aforesaid criteria. Later on, group I was given sterile NS $10 \mathrm{ml} / \mathrm{kg}$; group II received standard drug paracetamol $150 \mathrm{mg} / \mathrm{kg}$; and group III, IV, and V were given plant extract 50,100, and $200 \mathrm{mg} / \mathrm{kg}$, via i.p. route of administration, respectively. Rectal temperature was then noted directly at $0 \mathrm{~h}$ and after $1,2,3$, and $4 \mathrm{~h}$ post drug treatment $[23,24]$.

\section{Sterility test}

Preparations were intended to be injected through intraperitoneal route of administration, so they needed to comply with sterility protocol. Following the standards of the International Pharmacopoeia, we cross-checked by carrying out sterility test using fluid thioglycolate medium for anaerobic microbes and soya bean-casein medium for aerobic microbes, incubated for 14 days with preparations separately under the same conditions in which original tests were performed. The intended preparations were inoculated with equal volumes of mentioned medium. Thereafter, we have checked the appearance of any visible growth of microbes at 3rd, 5th, 7th, 9th, 11th, and 14th day after inoculation. In macroscopic examination, no visible growth or turbidity were observed in any of the culture plate. Hence, it was ascertained that plant extract and standard drugs used earlier were all sterile by replicating the similar conditions as were used during experiments [23].

\section{In vitro anti-proliferation test Cell culture}

Human breast cancer cell lines MCF-7, Skbr3, and MDA-MB-231 were provided by the Centre of Excellence in Molecular Biology (CEMB), PU Lahore. Receptor-based classification categorizes these cells into estrogen positive (ER+), e.g., MCF-7, Human epidermal growth factor receptor-2 positive (HER2), e.g., Skbr3 and triple-negative breast cancer (TNBC) type cancer cells, which do not possess any of the classical receptors of breast cells, e.g., MDA-MB-231 cell line. The MCF-7 cells were cultured in DMEM and Skbr3 cells were cultured in RPMI 1640, whereas MDA-MB-231 cells were grown in L15 complete medium; all the medium were supplemented with $10 \%$ FBS $(\mathrm{v} / \mathrm{v})$ and $1 \%$ penicillinstreptomycin solution (v/v) at $37{ }^{\circ} \mathrm{C}, 5 \% \mathrm{CO}_{2}$, and $95 \%$ relative humidity except for MDA-MB-231 cell line, which was incubated in $\mathrm{CO}_{2}$-free environment.

\section{MTT assay}

The cytotoxic potential of EG whole plant extract was appraised as described before with slight modifications. Briefly, the cells were seeded into 96-well plate at a density of $2 \times 10^{4}$ cells/well and incubated for $24 \mathrm{~h}$, followed by the treatment with different dilutions of plant extract $(0.78,1.56,3.12,6.25,12.5,25,50,100 \mu \mathrm{g} / \mathrm{ml})$ for $48 \mathrm{~h}$. After $48 \mathrm{~h}$, MTT reagent $(5 \mathrm{mg} / \mathrm{ml})$ was added in each well with serum-free medium $(200 \mu \mathrm{l})$ and subjected to further incubation for 4-6h; thereafter, the contents were removed from each well. In order to dissolve the formed crystals of purple formazan, $150 \mu \mathrm{l}$ of DMSO was added to each well and kept for $20 \mathrm{~min}$ at $37^{\circ} \mathrm{C}$ on an orbital shaker for $15 \mathrm{~min}$. The absorbance was then calculated using an ELISA plate reader at 490 
$\mathrm{nm}$. Absorbance of control (without any treatment) was used as reference for calculation of cytotoxicity and cell viability [25].

\section{Statistical analysis}

All the data were expressed in terms of mean \pm S.D. The experimental results were analyzed for statistical significance by one-way ANOVA followed by post hoc Dunnett's test for multiple comparisons. $p<0.05^{*}$ was considered significant.

\section{Results}

\section{Anti-inflammatory activity}

In carrageenan-induced paw edema, the plant extract demonstrated dose-dependent anti-inflammatory activity. The maximum anti-inflammatory activity (59.12\%) of the plant extract was noticed at a dose level of 200 $\mathrm{mg} / \mathrm{kg}$ as compared to the reference drug indomethacin $10 \mathrm{mg} / \mathrm{kg}$ with $81.97 \%$ of edema inhibition (Fig. 1).

\section{Analgesic activity}

The study demonstrated that the plant extracts EG revealed substantial peripheral as well as central analgesic trait, at a dose strength of $200 \mathrm{mg} / \mathrm{kg}$. The central analgesic property was evaluated and the plant extract of EG displayed dose-dependent increase in latency time of lifting the paw on Eddy's hot plate and the analgesic potential was found to be $61 \%$ at $200 \mathrm{mg} / \mathrm{kg}$ dose as compared to $86 \%$ for reference drug tramadol $20 \mathrm{mg} / \mathrm{kg}$. The results for latency time were recorded at 0,20 , and $60 \mathrm{~min}$ (Fig. 2).
The peripheral analgesic activity was estimated by acetic acid-induced writhing model and the number of writhings were counted for $60 \mathrm{~s}$ and $20 \mathrm{~min}$ after injection of $1 \%$ acetic acid to all groups. The difference between the number of writhing's in the control group and treatment groups was then calculated and percentage analgesia was determined. Plant extract produces a $27 \%$ decrease at $50 \mathrm{mg} / \mathrm{kg}, 41 \%$ at $100 \mathrm{mg} / \mathrm{kg}$, and $46 \%$ at 200 $\mathrm{mg} / \mathrm{kg}$ dose in writhing response when compared with the control group. The maximum analgesic strength of the plant extract for peripheral analgesic activity was found to be $46 \%$ at a dose strength of $200 \mathrm{mg} / \mathrm{kg}$ as compared to $64 \%$ for indomethacin taken as standard (Fig. 3).

\section{Antipyretic activity}

Antipyretic activity of aqueous methanolic extract of plant was calculated by first inducing pyrexia to experimental animals and then injecting various concentration of plant extract and compared against established reference drug and negative control groups. The plant extract at $200 \mathrm{mg} / \mathrm{kg}$ showed significant antipyretic potential against brewer's yeast-induced pyrexia in animal model. The rectal temperature of ER was recorded immediately at $0 \mathrm{~h}$, then after $1,2,3$, and $4 \mathrm{~h}$, after the plant extract treatment. The results compiled thus showed that aqueous methanolic extract of EG whole plant demonstrates significant antipyretic activity at dose of $200 \mathrm{mg} / \mathrm{kg}$ comparable to the reference drug paracetamol used at a dose of $150 \mathrm{mg} / \mathrm{kg}$ (Fig. 4).

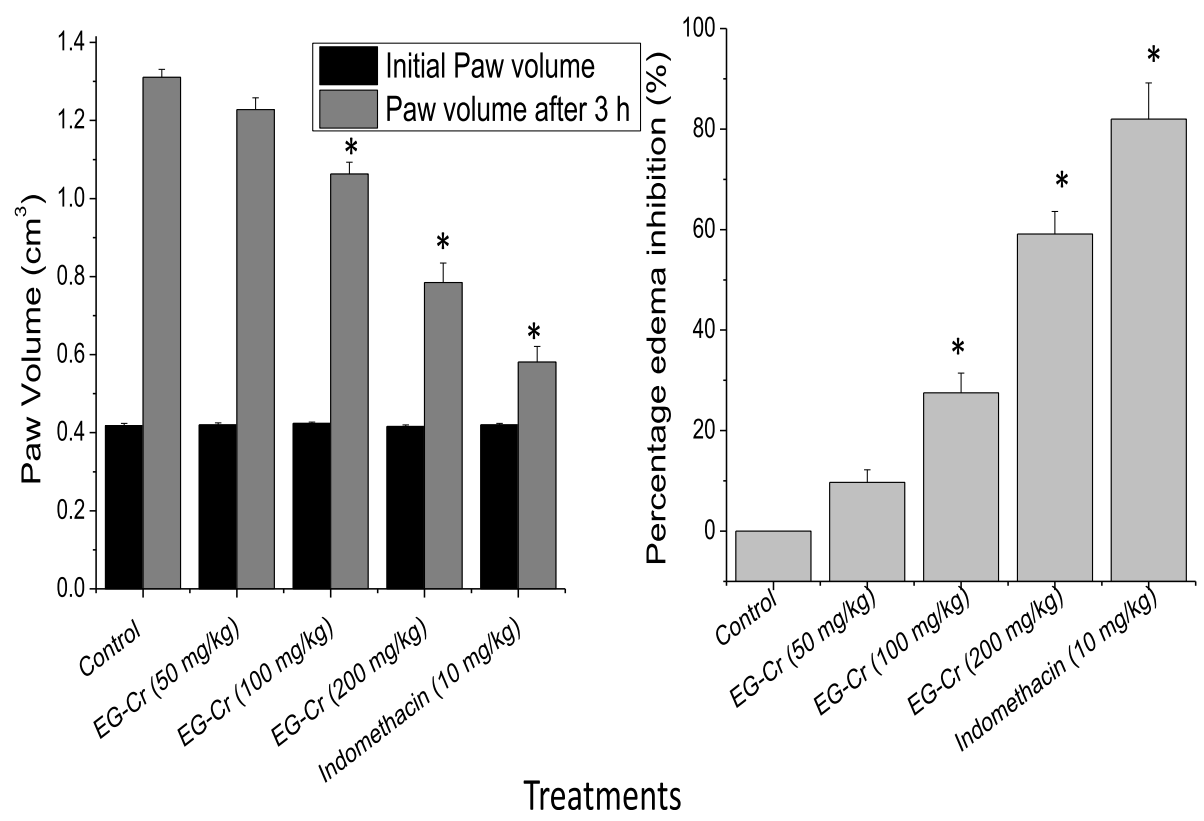

Fig. 1 a Anti-inflammatory effects demonstrated as paw volume and $\mathbf{b}$ as percentage inhibition $3 \mathrm{~h}$ after group treatment of EG $(n=4)$. Asterisk shows significant difference $(p<0.05)$ between treated group and control 

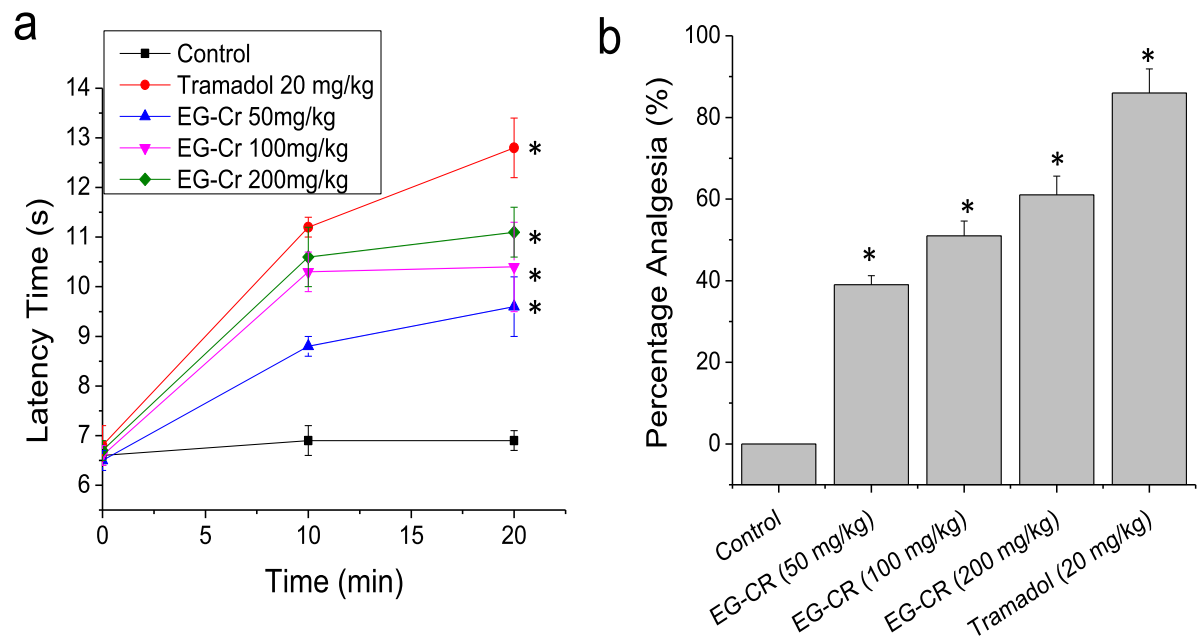

Fig. 2 a Analgesic property demonstrated as latency time after different time intervals of dose administration and $\mathbf{b}$ percentage analgesia of plant extract $(n=4)$. Asterisk shows significant difference $(p<0.05)$ between treated group and control

\section{Anti-proliferation activity}

The results of MTT assay using aqueous methanolic extract of whole plant EG are shown in Fig. 5. The findings of MTT assay indicated that the under-observation plant extract at given doses did not show any significant antiproliferation activity in breast cancer cell lines MCF-7, Skbr3, and MDA-MB-231 (Fig. 5).

\section{Discussion}

Therapeutically valued substances of plant origin were used as a source of treatment strategy against various pathological conditions in ancient days. In folk medicine, these plants derived substances were used for many years in curing of various ailments including fever, pain, and inflammation [26]. The plant EG is one of the better reported plants with several therapeutic applications. It was chosen to evaluate and validate the scientific basis of its traditional use for the aforesaid conditions [27]. In the current study, the plant EG was evaluated for its antiproliferative, anti-inflammatory, analgesic, and antipyretic potential. Aqueous methanolic extracts of whole plant of EG was prepared according to methods previously described [28]. Carrageenan-induced inflamed paw model was used to evaluate anti-inflammatory activity of EG
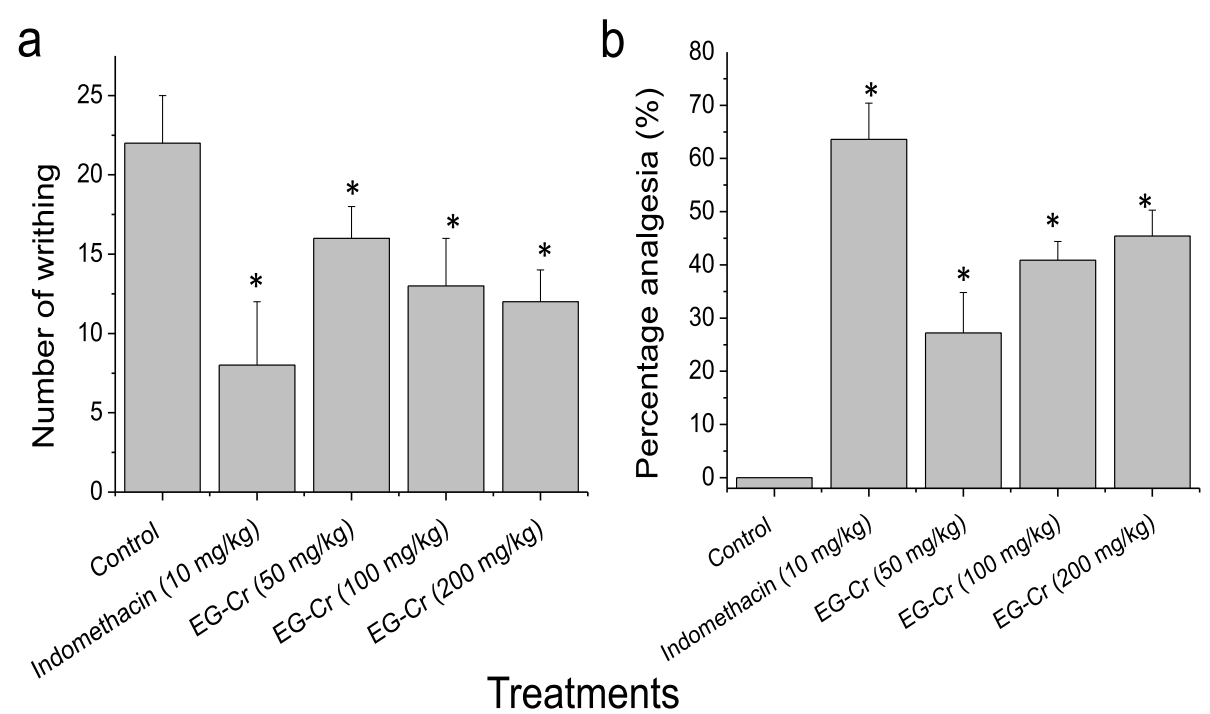

Fig. 3 a Peripheral analgesic potential demonstrated by number of writings and $\mathbf{b}$ as percentage analgesia of plant extract for 20 min after i.p. administration of given doses of EG aqueous methanolic extract at 50, 100, and $200 \mathrm{mg} / \mathrm{kg}$ doses $(n=4)$. Asterisk shows significant difference $(p$ $<0.05$ ) between treated group and control 


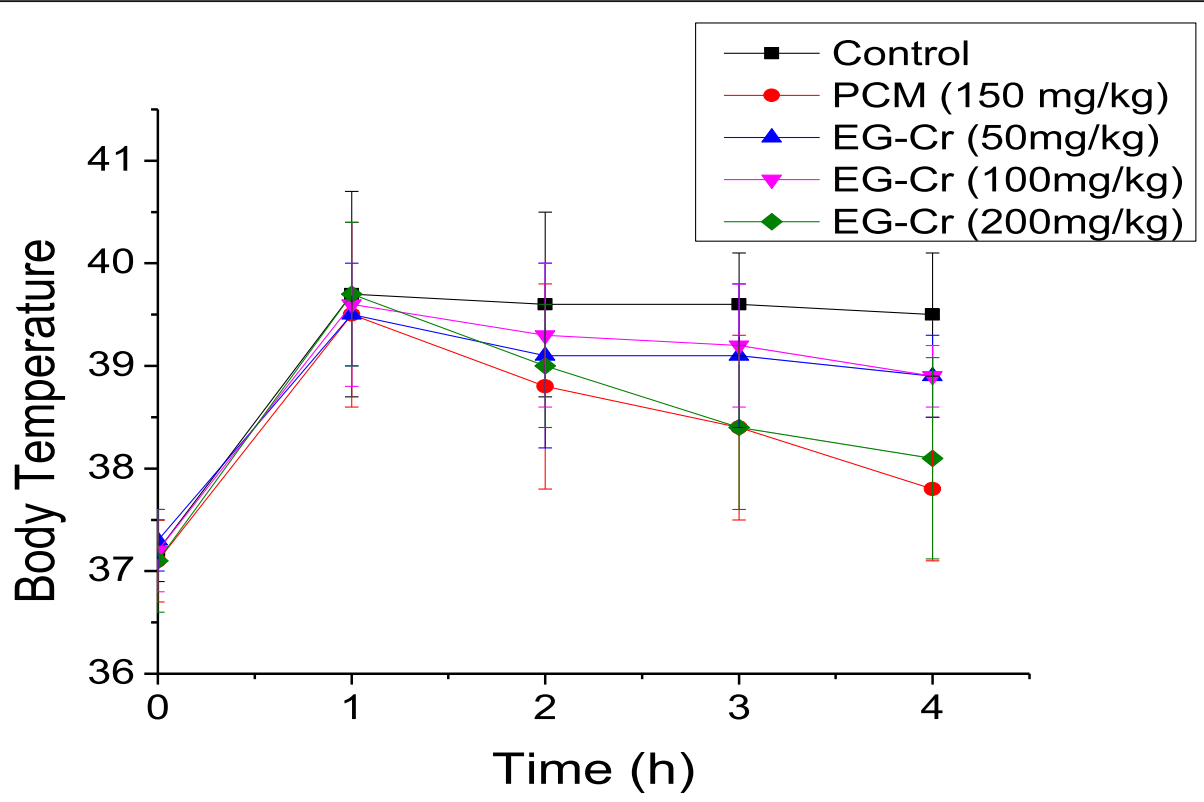

Fig. 4 Body temperature after treatment of pyrexia in ER $(n=4)$. Asterisk displays significant variance $(p<0.05)$ between treated groups reference and negative control group

extract. The release of certain inflammatory and proinflammatory substances, e.g., histamine, bradykinin, prostaglandins, and leukotrienes, are influenced by carrageenan [29]. Indomethacin was taken as standard control for the anti-inflammatory test of plant extract. The onset of paw edema prompted by carrageenan is a biphasic event. In the first phase of episode, the discharge of numerous inflammatory mediators occurs, e.g., kinins, histamine, and serotonin, while the second phase is primarily connected with the discharge of bradykinins and prostaglandins [30]. The size of the paw was taken as the parameter, to quantify inflammation and resultant increase in size is directly proportional to edema. The outcome of the statistical analysis has shown that plant extract at dose strength of $200 \mathrm{mg} / \mathrm{kg}$ produced a significant $(p<0.05)$ decrease in edema after $3 \mathrm{~h}$, of treatment. The plant extract exhibits graded dose response relationship against edema and it was noted that at $200 \mathrm{mg} / \mathrm{kg}$ dose, it produced 59\% decrease in edema. The acute inflammatory model used in research studies is generally established
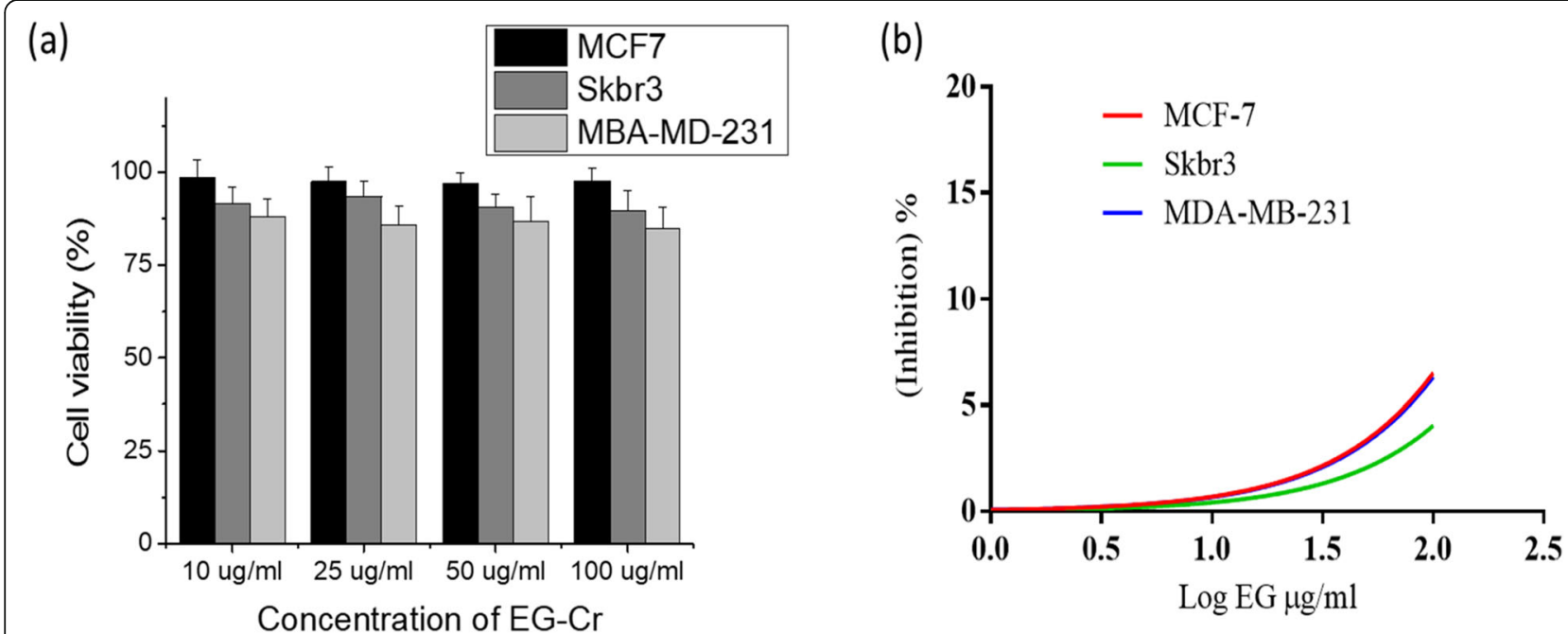

Fig. 5 Cell viability and dose inhibition curves for breast cancer cells (MCF-7, Skbr3, MDA-MB-231). a Cell viability of receptor-based classified breast cancer cell lines incubated for $48 \mathrm{~h}$ with different concentrations of EG-CR extract. $\mathbf{b}$ Dose inhibitory curve in breast cancer cell lines against log of different concentration of EG extract $(n=4)$ 
by carrageenan chemical that is subtle to cyclooxygenase inhibitors [31]. This model is most frequently used to find out the result of NSAID's which favorably detain cyclooxygenase enzyme involved in prostaglandin synthesis [32]. Although lipoxygenases and cyclooxygenase both pathways are connected with facilitating inflammatory development but inhibitors of the cyclooxygenase rather than lipoxygenases pathway are assumed to be more useful [33]. The process of inflammation is coupled with an increase in number of prostaglandins, leukocytes, and numerous other inflammatory mediators at the specific site [34]. The anti-inflammatory properties of plant extract EG consequently related with the inhibition of cyclooxygenase enzyme which in turn stops prostaglandin synthesis $[35,36]$. In addition to that, flavonoids are the chemicals which constrain prostaglandin synthetase enzyme activity, so the estimation of antiinflammatory potential also confirms the existence of flavonoids in the plant extract [37]. Substances involved in attenuating sensations of pain are termed analgesic. These agents are way different from anesthetics, because the later induce a reversible or temporary lessening in pain perception. The writhing movements are instigated by the peritoneal receptors that exist in the abdominal region. Discharge of various endogenous substances, e.g., arachidonic acid is the cause of pain initiation [38]. In acetic acid-triggered writhing model, the root cause of pain is the native discharge of arachidonic acid and prostaglandins. Administration of acetic acid causes release of certain endogenous substances that excite nerve endings of pain receptors [39]. Aqueous methanol extract of EG demonstrate significant peripheral analgesic effects that is comparable to that of standard drug indomethacin. The induction of writhing model for evaluation of peripheral analgesic effect is thought to be classier than tail flick model. Local peritoneal receptors are supposed to be involved in abdominal contraction response [40]. Evidence advocates an increase in level of lipoxygenase and that of PGF2 $\alpha$ and PGE2 in peritoneal fluid. It is also believed that there occurs an increase synthesis of nitric oxide. The drug tramadol resembles opioid in its mode of action. Investigational aqueous methanolic plant extract showed dose-dependent increase in central analgesic effects. The mechanism through which the plant extract possibly exerts this effect is the inhibition of prostaglandin biosynthesis [41]. The algesia is a two-step progression. In the first phase, stimulation of nociceptors occurs, possibly due to the role of bradykinins and substance $P$. In the second phase, serotonin, histamine, and prostaglandins are produced causing inflammation. Central analgesic agents inhibit both steps of pain progression, whereas peripheral analgesics can only be able to avert the second phase of the pain perception [42]. In our study, the plant extract exhibited inhibition of both the phases of pain progression, and consequently associated with both central as well as peripheral analgesic qualities. Agents that are able to reduce raised body temperature in certain pathological conditions are generally known as antipyretic substances. In our study, administration of brewer's yeast suspension to the experimental animals results in increase in prostaglandins synthesis and onset of pyrexia [43]. It is a valuable model for evaluating antipyretic activity not only for the plant-derived substances but also for the synthetically produced chemicals. Pyrexia induction to the animal model by injecting yeast suspension is called pathogenic fever, and it is associated with increased prostaglandin production [44]. The plant extract constrains cyclooxygenase enzyme subsequently decreases the discharge of prostaglandins as a result poses its antipyretic properties. The i.p. administration of plant extract has displayed substantial antipyretic trait in the brewer's yeast elicited pyrexia in animal model. Anti-proliferative potential of the plant extract was evaluated against using cell proliferation assay previously described with little modifications [45]. MTT assay is the most common way to ascertain anti-proliferative potential of the various substances, using different dilutions. In our study, however, EG extract showed no significant antiproliferative activity against receptor-based classified different types of breast cancer cell lines. Moreover, further purification of the plant extract will be required to optimize the therapeutically acceptable dose range as well as the toxicity studies, for maximizing the best possible therapeutic window, that may be used in the future as an alternative treatment strategy. In addition to that, dose adjustment with maximum tolerability to the normal cells and maximum sensitivity to tumor cells may be applied to different tumor models, so as to ascertain potential anti-proliferation activity of the under observation EG plant extract.

\section{Conclusion}

Overall findings of our study revealed that EG aqueous methanol extract has got significant anti-inflammatory, antipyretic, and analgesic properties at dose strength of $200 \mathrm{mg} / \mathrm{kg}$. However, no significant in vitro, antiproliferative activity of plant extract was observed with various dose-dilutions. Moreover, in the future, further studies will be required, as far as extended therapeutic use of under-observation plant is concerned, to advocate its dose related anti-proliferation property, within tolerable range to the growth of normal cells and at the same time toxic to cancer cells, in various cancer models.

\section{Supplementary Information}

The online version contains supplementary material available at https://doi. org/10.1186/s43094-021-00184-9.

Additional file 1:. 1. Anti-inflammatory activity. 2. Analgesic activity (central). 3. Analgesic activity (central). 4. Analgesic activity (central). 5 Anti-Proliferative activity.

\section{Abbreviations}

EG: Euphorbia granulata; ER: Experimental rats; NS: Normal saline; i.p.: Intraperitoneal; DMSO: Dimethyl sulfoxide; DMEM: Dulbecco's modified eagle 
medium; RPMI: Roswell Park Memorial Institute; PBS: Phosphate buffer saline; IPNI: International Plant Names Index; MTT: (3-(4,5-Dimethylthiazol-2-yl)-2,5diphenyltetrazolium bromide); ELISA: Enzyme-linked immunosorbent assay; NSAID: Non-steroidal anti-inflammatory drugs; DCM: Dichloromethane; FBS: Fetal bovine serum; $\mathrm{CO}_{2}$ : Carbon dioxide; CEMB: Centre of Excellence in Molecular Biology; ER+: Estrogen receptor positive; HER2: Human epidermal growth factor receptor-2; TNBC: Triple-negative breast cancer

\section{Acknowledgements}

We are thankful to the Institute of Pharmaceutical Sciences, University of Veterinary and Animal Sciences, Lahore, Pakistan, for providing facilities to conduct part of our research work. We are highly thankful to all laboratory staff of pharmacology department, who were always there for assistance during the University off hours as well.

\section{Plant authentication}

Botanical identification of under-observation plant Euphorbia granulata Forssk. was done from Government College University Lahore, and a sample was retained there in the herbarium with a voucher number 3820/Bot. Moreover, the plant name has also been checked with http://www.theplantlist.org for the accepted name in accordance with the International Plant Names Index (IPNI).

\section{Authors' contributions}

MAG and LI designed all experiments, performed experiments, and wrote manuscript. AR analyzed the data. UH and NA technical assistance and support. AJ supervised the work and provided reagents and information. The authors read and approved the final manuscript.

\section{Funding}

None

\section{Availability of data and materials}

Data and material are available upon request.

\section{Ethics approval and consent to participate}

Animal experimentation were performed after the approval from University animal experiment ethical committee (Institutional Review Committee for Biomedical Research University of Veterinary and Animal Sciences Lahore, Pakistan) IRCBR/886-E-17/PCOL/UVAS, as no toxicity study was involved in our research work; the rats were given to the animal house of the university in good health condition.

\section{Consent for publication}

Not applicable

\section{Competing interests}

Authors declare no competing interest.

\section{Author details}

'Department of Pharmacology and Toxicology, University of Veterinary and Animal Sciences, Lahore, Pakistan. ${ }^{2}$ University College of Pharmacy, University of the Punjab, Lahore, Pakistan. ${ }^{3}$ Center of Drug Safety and Policy Research, School of Pharmacy, Xi'an Jiao Tong University, Xi'an, Shaanxi, China.

Received: 21 February 2020 Accepted: 12 January 2021

Published online: 04 February 2021

\section{References}

1. Semwal DK, Badoni R, Semwal R, Kothiyal SK, Singh GJP, Rawat U (2010) The genus Stephania (Menispermaceae): chemical and pharmacological perspectives. J. Ethnopharmacol. 132(2):369-383

2. Shinwari ZK (2010) Medicinal plants research in Pakistan. J Med Plants Res. 4(3):161-176

3. Jan G, Khan MA, Farhatullah JF, Ahmad M, Jan M, Zafar M (2011) Ethnobotanical studies on some useful plants of Dir Kohistan valleys, KPK, Pakistan. Pak J Bot 43(4):1849-1852

4. Webster GL (2014) Euphorbiaceae. In Flowering plants. Eudicots (pp. 51216). Springer, Berlin, Heidelberg.

5. Tona L, Cimanga RK, Mesia K, Musuamba CT, De Bruyne T, Apers S, Vlietinck AJ (2004) In vitro anti-plasmodial activity of extracts and fractions from seven medicinal plants used in the Democratic Republic of Congo. J. Ethnopharmacol. 93(1):27-32

6. Hussein G, Miyashiro H, Nakamura N, Hattori M, Kawahata T, Otake T, Shimotohno K (1999) Inhibitory effects of Sudanese plant extracts on HIV-1 replication and HIV-1 protease. Phytother Res 13(1):31-36

7. Schmelzer GH, \& Gurib-Fakim, A (2008) Plant resources of tropical Africa 11 (1). Medicinal plants 1. PROTA foundation.

8. Kumar S, Malhotra R, Kumar D (2010) Euphorbia hirta: Its chemistry, traditional and medicinal uses, and pharmacological activities. Pharmacogn Rev. 4(7):58

9. Bhowmick R, Sarwar MS, RahmanDewan SM, Das A, Das B, NasirUddin MM, Islam MS (2014) In vivo analgesic, antipyretic, and anti-inflammatory potential in Swiss albino mice and in vitro thrombolytic activity of hydroalcoholic extract from Litsea glutinosa leaves. Biol Res. 47(1):56

10. Kumar S, Vandana UK, Agrwal D, Hansa J (2015) Analgesic, antiinflammatory and anti-pyretic effects of Azadirachta indica (Neem) leaf extract in albino rats. Int J Sci Res. 4:713-721

11. Arul V, Miyazaki S, Dhananjayan R (2005) Studies on the anti-inflammatory, antipyretic and analgesic properties of the leaves of Aegle marmelos Corr. J. Ethnopharmacol. 96(1-2):159-163

12. Parveen A, Akash MSH, Rehman K, Mahmood Q, Qadir MI (2014) Analgesic, anti-inflammatory and anti-pyretic activities of Caesalpinia decapetala. Biolmpacts 4(1):43

13. Falodun A, Okunrobo LO, Uzoamaka N (2006) Phytochemical screening and anti-inflammatory evaluation of methanolic and aqueous extracts of Euphorbia heterophylla Linn (Euphorbiaceae). Afr J Biotechnol. 5(6):529-531

14. Daqama FJD, Yaseen NY, Altaae EHY, Al-Naimi RAA (2010) Pathological study of therapeutic effect of crude extract of Euphorbia granulata F. in experimentally implanted murine mammary adenocarcinoma. Al-Anbar J Vet Sci 3(2):89-98

15. Konya RS, Leelee LF, Chukwu KO (2013) In vitro evaluation of the effect of Euphorbia kamerunica latex on the blood of albino rat (Rattus norvegicus). Anim Res Int. 10(3):1747-1751

16. Mohamed HM, Aly MS (2018) Evaluation of genotoxicity of Euphorbia triaculeata Forssk. extract on mice bone marrow cells in vivo. Toxicol Rep. 5:625-631

17. Saleem U, Ahmad B, Ahmad M, Hussain K, Bukhari NI (2014) Investigation of in vivo antioxidant activity of Euphorbia helioscopia latex and leaves methanol extract: a target against oxidative stress induced toxicity. Asian Pac J Trop Med. 7:S369-S375

18. Sunday EA, Onyeyili PA, Saganuwan SA (2019) Therapeutic effects of Byrsocarpus coccineus root bark extract on bacterially and chemically induced diarrhea in the Wistar albino rat (Rattus norvegicus domestica). Anim. Mod. Exp. Med.

19. Okoro SO, Kawo AH, Arzai AH (2012) Phytochemical screening, antibacterial and toxicological activities of Acacia senegal extracts. Bayero J Pure Appl Sci. 5(1):163-170

20. Fereidoni M, Ahmadiani A, Semnanian S, Javan M (2000) An accurate and simple method for measurement of paw edema. J Pharmacol Toxicol Methods. 43(1):11-14

21. Hajare SW, Chandra S, Tandan SK, Sarma J, Lal J, Telang AG (2000) Analgesic and antipyretic activities of Dalbergia sissoo leaves. Indian J Pharmacol. 32(6):357-360

22. Al-Ghamdi MS (2001) The anti-inflammatory, analgesic and antipyretic activity of Nigella sativa. J Ethnopharmacol. 76(1):45-48

23. Gupta MB, Nath R, Srivastava N, Shanker K, Kishor K, Bhargava KP (1980) Anti-inflammatory and antipyretic activities of $\beta$-sitosterol. Planta Med. 39(06):157-163

24. World Health Organization. (2012). http://www.who.int.Document QAS/11.413.Final.

25. van Meerloo J, Kaspers GJ, Cloos J (2011) Cell sensitivity assays: the MTT assay. In: Cree IA, editor. Cancer cell culture: Methods and Protocols. Totowa: Humana Press; p. 237-45.

26. Amdekar S, Roy P, Singh V, Kumar A, Singh R, Sharma P (2012) Antiinflammatory activity of lactobacillus on carrageenan-induced paw edema in male wistar rats. Int. J. Inflamm. 2012

27. Ghauri MA, Khan GJ, Khan S, Javeed A, Naeem H, Ashraf M (2017) In-vivo evaluation of analgesic, anti-inflammatory and anti-pyretic activity of aqueous methanolic extract of Jatropha gossypifolia. Afr J Pharm Pharmacol. 11(30):355-361

28. Abu Bakar Fl, Abu Bakar MF, Abdullah N, Endrini S, Fatmawati S (2020) Optimization of extraction conditions of phytochemical compounds and 
anti-gout activity of Euphorbia hirta L. (Ara Tanah) using response surface methodology and liquid chromatography-mass spectrometry (LC-MS) analysis. Evid. Based Complement. Alternat. Med. 2020.

29. Ahmad F, Khan RA, Rasheed S (1992) Study of analgesic and antiinflammatory activity from plant extracts of Lactuca scariola and Artemisia absinthium. J Islam Acad Sci. 5(2):111-114

30. Singh A, Malhotra S, Subban R (2008) Anti-inflammatory and analgesic agents from Indian medicinal plants. Int J Integr Biol. 3(1):57-72

31. Moura LFWG, da Silva Neto JX, Lopes TDP, Benjamin SR, Brito FCR, Magalhães FEA, Guedes MIF (2019) Ethnobotanic, phytochemical uses and ethnopharmacological profile of genus Cnidoscolus spp. (Euphorbiaceae): a comprehensive overview. Biomed Pharmacother. 109:1670-1679

32. Qadir Ml, Abbas K, Hamayun R, Ali M (2014) Analgesic, anti-inflammatory and anti-pyretic activities of aqueous ethanolic extract of Tamarix aphylla $\mathrm{L}$. (Saltcedar) in mice. Pak J Pharm Sci 27(6):1985-1988

33. Saleem H, Zengin G, Locatelli M, Mollica A, Ahmad I, Mahomoodally FM, Ahemad N (2019) In vitro biological propensities and chemical profiling of Euphorbia milii Des Moul (Euphorbiaceae): a novel source for bioactive agents. Ind Crops Prod. 130:9-15

34. Ramachandran S, Rajasekaran A, Kumar KM (2011) Evaluation of antiinflammatory and analgesic potential of methanol extract of Tectona grandis flowers. Asian Pac J Trop Biomed. 1(2):S155-S158

35. Evans WC (2009). Trease and Evans pharmacognosy, International Edition EBook. Elsevier Health Sciences.

36. Tuhin RH, Begum MM, Rahman MS, Karim R, Begum T, Ahmed SU, Mostofa R, Hossain A, Abdel-Daim M, Begum R (2017) Wound healing effect of Euphorbia hirta linn. (Euphorbiaceae) in alloxan induced diabetic rats. BMC Complement Altern Med 17(1):423

37. Sengar N, Joshi A, Prasad SK, Hemalatha S (2015) Anti-inflammatory, analgesic and anti-pyretic activities of standardized root extract of Jasminum sambac. J. Ethnopharmacol. 160:140-148

38. Shekhawat N, Vijayvergia R (2010) Investigation of anti-inflammatory, analgesic and antipyretic properties of Madhuca indica GMEL. Eur J Inflam. 8(3):165-171

39. Muhammad N, Saeed M, Khan H (2012) Antipyretic, analgesic and antiinflammatory activity of Viola betonicifolia whole plant. BMC Complement Altern Med 12(1):59

40. Mbiantcha M, Kamanyi A, Teponno RB, Tapondjou AL, Watcho P, Nguelefack TB (2011) Analgesic and anti-inflammatory properties of extracts from the bulbils of Dioscorea bulbifera L. var sativa (Dioscoreaceae) in mice and rats, Evid Based Complement Alternat Med. 2011

41. Shukla S, Mehta A (2015) In vivo anti-inflammatory, analgesic and antipyretic activities of a medicinal plant, Caesalpinia bonducella F. Pak J Pharm Sci.:28

42. Sandrini G, Ruiz L, Capararo M, Garofoli F, Beretta A, Nappi G (1992) Central analgesic activity of ibuprofen. A neurophysiological study in humans. Int J Clin Pharmacol Res. 12(4):197-204

43. Chavan MJ, Wakte PS, Shinde DB (2010) Analgesic and anti-inflammatory activity of caryophyllene oxide from Annona squamosa L. bark. Phytomedicine 17(2):149-151

44. Bhukya B, Anreddy RNR, William CM, Gottumukkala KM (2009) Analgesic and anti-inflammatory activities of leaf extract of Kydia calycina Roxb. Banglad J Pharmacol. 4(2):101-104

45. Loux JJ, DePalma PD, Yankell SL (1972) Antipyretic testing of aspirin in rats. Toxicol Appl Pharmacol. 22(4):672-675

\section{Publisher's Note}

Springer Nature remains neutral with regard to jurisdictional claims in published maps and institutional affiliations.

\section{Submit your manuscript to a SpringerOpen ${ }^{\circ}$ journal and benefit from:}

- Convenient online submission

- Rigorous peer review

- Open access: articles freely available online

- High visibility within the field

- Retaining the copyright to your article

Submit your next manuscript at $\boldsymbol{\nabla}$ springeropen.com 